\title{
INNY HELLENIZM.
}

\section{OBRAZy BIZANCJUM W LITERATURZE MEODOPOLSKIEJ}

\author{
Kamil Szmid \\ kamil.szmid@gmail.com
}

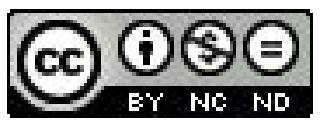

Tradycja bizantyńska w literaturze polskiej przez wieki nie odgrywała prawie żadnej roli. Sporadyczne wzmianki o Bizancjum znajdują się w kronikach średniowiecznych, na przykład u Jana Długosza. Carogród, czyli Konstantynopol, pojawia się czasem w poematach i wierszach romantycznych, choćby u Mickiewicza i Słowackiego ${ }^{1}$. Znamienitym przykładem ścierania się kultury średniowiecznej Polski z wpływami idei Cesarstwa Greckiego jest natomiast Bogurodzi$c a^{2}$. Brak jednakowoż, aż do początku XX wieku, dzieła osadzonego w realiach bizantyńskich bądź też w znacznej mierze korzystającego z dorobku średniowiecznego państwa rzymskiego. Pierwszym takim utworem jest Bazilissa Teofanu Tadeusza Micińskiego. Akcja owego dramatu o dość nierównym poziomie artystycznym rozgrywa się głównie na dworze bizantyńskim i opowiada historię przebiegłej cesarzowej (gr. $\left.\beta \alpha \sigma \iota \iota \_\sigma \alpha\right)$ Teofano, żony władców Romana II i Nikefora Fokasa oraz kochanki Jana Tzimiskesa. Sztuka Micińskiego została jednak wydana wiele lat po jej ukończeniu i nie wpłynęła na zainteresowania epoki. Równolegle wzmianki o Bizancjum pojawiają się w twórczości Stefana Żeromskiego, mianowicie w powieści Popioły. Refleksja nad obrazem Bizancjum w obu tych tekstach będzie głównym celem poniższego tekstu.

Europa w V wieku podzieliła się na dwie części: rzymski Wschód i, po upadku Cesarstwa Zachodniorzymskiego, barbarzyński Zachód. Przywódcą rodzącego się Bizancjum pozostawał cesarz, któremu podporządkowani byli wszyscy patriarchowie wschodni, potęgą jednoczącą państwa sukcesyjne na Zachodzie pozostawał natomiast papież, niechętny dominacji cesarskiej. Stopniowo różnice pomiędzy dwoma częściami Europy ulegały pogłębieniu, a ukoronowaniem tego procesu była schizma kościołów w 1054 r. Już jednak w IX wieku doszło do nieodwracalnego podziału kulturowego na zachodnią latinitas i wschodnia, grecko-słowiańską cyryllianitas. Przez długi jeszcze okres to Bizancjum pozostawało największą potęgą europejską. Okres świetności Wschodu zakończył się wraz z IV krucjatą w 1204 r., kiedy krzyżowcy pod wodzą Wenecji zdołali pokonać siły cesarskie. Ta grabieżcza wyprawa obróciła w perzynę dotychczasowy porządek, inicjując dominację Zachodu. Podbój pociągną za sobą umocnienie pejoratywnych, zapoczątkowanych przecież przez św. Grzegorza z Tours już w VI wieku³, zachodnich przekonań o państwach kręgu prawosławnego. Wschód - najpierw grecko-słowiański, później rosyjsko-turecki-odizolował się od Europy universalis, która każdorazowo konstytuowała się w kontrapozycji wobec Bałkanów i caratu. Orient, bliższy czy dalszy, był dokładnym przeciwieństwem Okcydentu; dyskurs zachodnioeuropejski operując wartościującymi zestawieniami budował swoją tożsamość i tym samym stygmatyzował Wschód. Maria Janion, komentując w Niesamowitej słowiańszczyźnie rozprawę Karola Potkańskiego Konstantyn i Metodyusz z 1905 r., stwierdzała:

Dla przykładu: „Na szczycie jaka łuna! pożar Carogrodu!”. A. Mickiewicz, Widok gór ze stepów Kozłowa, [w:] tenże, Wybór poezyj, t. 1, Wrocław 1974, w. 5; „,Cóż to za gwiazda we mgle się pali? Ho! to latarnia z wież Carogrodu”. J. Słowacki, Żmija, [w:] tenże, Poematy, Krzyżanowski J. (red.), Wrocław 1959, w. 811-812.

2 Wśród zwolenników tzw. hipotezy bizantyńskiej, według której inspiracje dla utworu zostały zaczerpnięte z kręgu grecko- słowiańskiego, wymienić można m.in. Józefa Birkenmajera, Tadeusza Lehra- Spławińskiego, Juliana Krzyżanowskiego czy Tadeusza Milewskiego.

3 Św. Grzegorz z Tours, Historie. Historia Frankóww, T. Richter, Tyniec-Kraków 2002. 
„Wschodowi w tym ujęciu zabrakło wielkości w każdym znaczeniu: nie nadążał za postępem dziejowym, nawet jego skarb - dziedzictwo greckie -Zachód lepiej rozumiał; jego radykalna herezja tchnęła azjatyckim mistycyzmem. Nic dziwnego, że pod koniec rozprawy Potkański stwierdzał, że tylko Kościół zachodni wychował europejskie społeczeństwo. Ludy słowiańskie, takie jak polski, »nie mają powodu żałować, że z Zachodem poszły, bo ostatecznie w wielkim cywilizacyjnym pochodzie Zachód zwyciężył i on jeden pozostał «"4.

Brak zrozumienia, będący wynikiem kulturalno-mentalnościowej przepaści pomiędzy Europą katolicką a ortodoksyjna, powodował, iż ludzie Zachodu kreowali orientalizujący wizerunek Cesarstwa i jego mieszkańców. Bizancjum było opisywane jako siedlisko zepsucia i rozpusty. Jeszcze większą nietolerancję okazywano wobec Bizantyńczyków, którzy, najczęściej w związku z małżeństwami dynastycznymi, przenosili się na Zachód. Kiedy Maria Argyropulena przybyła ze swoim orszakiem do Wenecji i wprowadziła na dwór doży nowe obyczaje (nawiasem mówiąc - Maria przywiozła do Zachodniej Europy widelec i tym samym stworzyła nową modę), natychmiast pojawiły się głosy oburzenia wśród lokalnego duchowieństwa:

„Piotr Damian [biskup wenecki - dop. K. S.] wspomina Marię jako przykład niegodzien naśladowania. Niedość, że bardzo ostro ją krytykuje, to jeszcze zarzuca, że żyła w bardzo delikatny i sztuczny sposób, ponieważ nie zgadzała się na kąpiel w ściekach komunalnych Wenecji i poleciła swym sługom zbieranie wody deszczowej. Maria perfumowała swoje komnaty tymiankiem i innymi aromatami, "złym i haniebnym smrodem «, który przyczynił się do straszliwych kar, jakie spotkały ją w trakcie epidemii w 1006 roku" $^{\prime 2}$.

Mieszkańcy Zachodu uważali Bizantyńczyków za lud dumny, wyniosły, a jednocześnie przebiegły i okrutny. Mężczyźni byli postrzegani jako zniewieściali i niezdolni do walki, a stereotyp ten powstał wskutek obserwacji bizantyńskich eunuchów. Kobiety zaś charakteryzowano jako rozkapryszone, przeintelektualizowane, wyuzdane i żądne władzy. Europejczycy uznali, że ustrój Cesarstwa był zbyt biurokratyczny, a całe Bizancjum - zacofane i słabe. Znana bizantynistka, Judith Herrin, słusznie stwierdza, iż oskarżenia te dalekie były od prawdy, lecz pokutowały jeszcze przez wieki ${ }^{6}$

Orientalizacja Bizancjum przez Zachód nie skończyła się wraz z upadkiem Konstantynopola w 1453 r. Trwała przez setki lat i po części, jak twierdzi Herrin, trwa do dziś. W XVIII wieku na nowo zainteresowano się Cesarstwem; wtedy też ukuto krzywdzące i pejoratywne określenia: „Bizancjum” i „bizantyński”. Cesarstwo Greckie przez cały okres swojego istnienia nigdy nie określało siebie tym mianem; wyraz byzantion był używany wyłącznie jako historyczna nazwa greckiej kolonii, na miejscu której powstał Konstantynopol. Oba wzmiankowane określenia stały się synonimem zepsucia i dekadencji (mimo to do dziś są używane na określenie średniowiecznego Rzymu). Reprezentatywnym przykładem XIX-wiecznej tendencji do wartościującej orientalizacji są słowa Williama Lecky'ego:

„Uniwersalny werdykt historii mówi, że Bizancjum bez jakiegokolwiek wyjątku stanowiło najpodlejszą i najbardziej nikczemną formę cywilizacji, jaka kiedykolwiek istniała. Nie było nigdy żadnej cywilizacji tak skrajnie wyzutej z jakiejkolwiek formy lub co najmniej cząstki chwały, żadnej do której epitet »nędzny« może być tak bezsprzecznie dopasowany... Historia tego imperium jest monotonną opowieścią o intrygach księży, eunuchów i kobiet, o konspiracjach i otruciach..."7.

4 M. Janion, Niesamowita stowiańszczyzna. Fantazmaty literatury, Kraków 2006, s. 214.

5 J. Herrin, Byzantium. The surprising life of medieval Empire, New Jersey 2007, s. 209.

Tamże, s. 335.

Cyt. za: tamże, s. 322. 


\section{Bizancjum MicińsKiego}

Konstatacja, iż słowa Lecky’ego mogłyby streścić kreację Bizancjum w Bazilissie Teofanu może wydawać się sporym uproszczeniem, jednak nie sposób nie dostrzegać w obu przypadkach tego samego kryterium aksjologicznego, opartego na opozycji wartości, uzurpowanych sobie przez Zachód, jak i tych, które na drodze wyparcia przypisane zostały Wschodowi. Jak bowiem manifestuje główna bohaterka sztuki Micińskiego: „Nikeforze - tu jest, zaprawdę, olbrzymi grzech ziemi - Bizancjum!"' W przypadku Lecky'ego demonizacja Orientu ma na celu dość oczywiste samopotwierdzenie zachodniej tożsamości. By zinterpretować przedstawienie średniowiecznej Grecji w Bazilissie, konieczne są jednak: konfrontacja przesłania dramatu z polskimi uwarunkowaniami kulturowymi oraz umiejscowienie dramatu w szerszej tradycji literackiej.

Polska przez całą swoją historię średniowieczną rozwijała się w oddaleniu od wpływów bizantyńskich. Mimo tak istotnego znaczenia prawosławia w pierwszej Rzeczypospolitej tradycję ortodoksyjna, ukonstytuowaną w kręgu bizantyńskim, kultywowano raczej na marginesie życia społecznego. Polacy w większości nie uważali się, w przeciwieństwie do wielu innych narodów słowiańskich, za spadkobierców Cesarstwa Greckiego i w związku z tym Bizancjum bywało najczęściej postrzegane przez pryzmat politycznego dyskursu zachodnioeuropejskiego. Mimo to Polska nieustannie tkwiła w tożsamościowym impasie - z jednej strony niepodobna było wyrzec się słowiańskości, z drugiej zaś odrzucić nie można było katolickiej latinitas gwarantującej państwu istnienie na uniwersalistycznej mapie Europy. Wspólnota religijna z Zachodem dawała iluzję bezpieczeństwa, podczas gdy pobratymstwo ze Wschodem mogłoby narazić na gniew Okcydentu i oznaczać wykluczenie z „właściwej” Europy oraz piętno inności:

„Między Zachodem łacińskim a Wschodem greckim, między Rzymem a Bizancjum zaczęła przebiegać przed tysiącem lat linia podziału religijno-kulturalnego, która bywa uznawana »za najtrwalszą granicę kulturalną kontynentu europejskiego«. [...] Polska znalazła się w położeniu zachodnio-wschodnim; jak to określa ironicznie Sławomir Mrożek: na wschód od Zachodu i na zachód od Wschodu. Usiłowała jednak najczęściej - myślą swych intelektualistów i potocznym wyobrażeniem - przeważyć szalę na rzecz »Zachodu« i odciąć od »Wschodu«" ${ }^{\prime 8}$.

W mrokach Złotego Pałacu można odczytać jako manifestacyjne opowiedzenie się po stronie zachodnioeuropejskiej formacji kulturowej, na której zafiksowane jest pragnienie skolonizowanej tożsamości. W dramacie nie tyle dokonuje się wyparcie słowiańsko-ortodoksyjnej autoidentyfikacji, skoro proces ten uznać można na początku XX wieku za względnie dopełniony w Polsce, co ustanawia się Zachód jako objet petit á, które zmusza do postponowania dziedzictwa uosabianego przez opresora - Rosję oraz ubogie słowiańskie państwa Bałkanów. Polskie „,ja" kształtuje się w opozycji do Wschodu, zarazem dokonując mimikry Zachodu rządzonej logiką "mimetycznego pożądania" - jak w teorii René Girarda. Dyskurs Okcydentu nie pozwala jednak w żadnym razie na inkorporowanie skolonizowanych tożsamości. Jak pisze najważniejszy teoretyk mimikry w dyskursie postkolonialnym, Homi Bhabha:

,[...] mimikra kolonialna to pragnienie zreformowanego, rozpoznawalnego Innego, jako podmiotu różnicy, który jest prawie taki sam, ale nie całkiem. Inaczej mówiąc, dyskurs mimikry tworzy się wokół dwuznaczności: aby była skuteczna, mimikra musi bezustannie demonstrować swoje ześlizgiwanie się znaczenia, swój nadmiar, swoją różnicę. Autorytet tej odmiany dyskursu kolonialnego, którą nazwałem mimikra, dotknięty jest wobec tego pewną nieokreślonością: mimikra jawi się jako przedstawienie różnicy, która sama jest procesem zaprzeczenia. Mimikra jest więc znakiem o podwójnej

\footnotetext{
8 Tamże, s. 11.
} 
artykulacji, złożoną strategią reformowania, porządkowania i dyscyplinowania, która wyobrażając sobie władzę, »przywłaszcza« sobie Innego" ${ }^{\prime \prime}$.

Polska skazana jest więc na status „przywłaszczonego” przez hegemona, jednak nigdy nie przestanie być „pomiędzy” - jak w ironicznym stwierdzeniu Mrożka.

Na przestrzeń przedstawioną w Bazilissie Teofanu wpływa zapoczątkowana w XIX wieku tendencja do silnej semantyzacji. Romantycy często umieszczali akcję swoich dramatów w dalekiej przeszłości, w miejscach na wpół-mitycznych i odległych od ojczyzny. Sztafaż w dramatach takich jak Lilla Weneda bądź Anhelli, mimo iż pozornie niezwiązany ze współczesnością Słowackiego, jest zawoalowanym przesłaniem dotyczącym kondycji narodu. Kolejnym przykładem jest Irydion Krasińskiego, w którym fantastyczna akcja rozgrywająca się na terenie upadającego Rzymu służy jako diagnoza XIX-wiecznych nastrojów narodowych. Przestrzeń w Bazilissie Teofanu równieżjest silnie naznaczona ideologicznie, jednakowoż trudno stwierdzić, czy dramat ów intencjonalnie miał wyrażać treści patriotyczne.

Estetyka i nastrojowość dramatu Micińskiego przypominają obrazy Gustave'a Moreau. Wnętrza są pełne przepychu, jednakże znaczna ich część jest spowita cieniem, gdzieniegdzie zaś pojawiają się słabe refleksy świetlne. Na złoto-ciemnym tle króluje demoniczna Salome, alter ego cesarzowej Teofano. Tak zarysowana przestrzeń w modernizmie była wyrazicielką filozofii epoki. Dekadentyzm u Micińskiego sygnalizuje swą obecność na płaszczyznach zarówno estetycznej, jak i fabularnej. Bizancjum w zamyśle twórcy stanowiło odpowiednie narzędzie do wyrażenia kryzysu cywilizacji europejskiej, bowiem hipertrofia kulturowa Cesarstwa Greckiego doprowadza do jego degrengolady i per analogiam - to samo czeka Europę przełomu wieków.

Miciński kreśli pejoratywny obraz Cesarstwa, a Grecy, których notabene jedyną reprezentację stanowi elita rządząca, jednoznacznie charakteryzowani sąjako okrutni, fałszywi i podstępni, do czego zresztą sami się przyznają:

„Synu Północy, jeżeliś słyszał o rodzie Atrydów i morderstwach, które zasiewał w bagnisku ich dusz grecki bóg Fatum - wiedz, iż te zbrodnie trawkami są wobec boru krwawego Konstantynoidów [błąd merytoryczny - nie wszyscy z wymienionych cesarzy byli członkami dynastii zapoczątkowanej przez Konstantyna Wielkiego - przyp. K.S.]. Ten w eliptycznym grobowcu jest ów Julian Apostata, nekrofil bogów, ożywiciel piekielnych widm Hadesu, sarkofag z zielonego marmuru z Hierapolis ma Justynian, najprzewrotniejszy tyran, udający się za Boga, papieża i cesarza w jednej osobie - którego żona Teodora, kurtyzana [Teodora była aktorką cyrkową - przyp. K.S.] z cyrku i córka pogromcy dzikich zwierząt, wyrżnęła sto tysięcy paulinianów - czcicieli Dobra! Tam leży Herakliusz - o czynach Aleksandra Macedońskiego - krótki meteor nad światem gnijącym"10.

Fabuła dramatu to ciąg zdrad, spisków, morderstw i porwań. Okrucieństwa przeplatają się z aktami nabożności: modlitwa poprzedza zbrodnię, pieśń religijna towarzyszy występkowi, religijność podszyta zostaje złem. Teofano jawi się w ustach bohaterów jako święta, mężczyźni porównują ją do Maryi lub anioła, tymczasem cesarzowa ujawnia swą prawdziwą tożsamość: „Jestem Marią Medeą" - krzyczy pod koniec aktu trzeciego. To paradoksalne zestawienie określa istotę bazilissy - splot piękna, świętości, demoniczności i okrucieństwa, reprezentowane przez chrześcijańską świętą i kontrowersyjną postać z mitologii greckiej. Cesarzowa hipnotyzuje mężczyzn swoją uroda, pozorowanymi: cnotą i nieskazitelnością moralną.

Pesymizm Micińskiego podważa wszelakie wartości - w patetycznej rzeczywistości Bazilissy

9 H. Bhabha, Mimikra i ludzie. O dwuznaczności dyskursu kolonialnego, „,Literatura na Świecie” 2008, nr 1-2, s. 185

10 T. Miciński, W mrokach złotego pałacu czyli Bazilissa Teofanu, [w:] tenże, Utwory dramatyczne, Kraków 1979, s. 14. 
Teofanu nic nie jest relewantne. Każdy akt dobroci to tylko pozór, a jedyną prawdziwie występującą kategorią aksjologiczną jest zło. Wizja Bizancjum u Micińskiego streszcza się w pierwszym członie tytułu „w mrokach złotego pałacu”. Cywilizacja bizantyńska wytworzona została bowiem nie przez rozum, jej kształt wynika raczej z atawizmów: żądz władzy i bogactwa, których źródło stanowi pierwotne zło. Ta paradoksalna wizja świata "niemożliwego" współgra z utrwalonymi zachodnimi przeświadczeniami dotyczącymi Cesarstwa Bizantyńskiego.

Konstantynopol w dramacie Micińskiego służy jako miejsce spotkań i quasi-dialogu pomiędzy różnymi kulturami. Pojawiają się w sztuce Normanowie, Rusini oraz Turcy. Przybysze żywią pogardę dla państwa greckiego i jego władców, ich usiłowania dążą do wniknięcia w strukturę władzy i destrukcji Cesarstwa od wewnątrz. Bizancjum jako „największy grzech ziemi” zasługuje według nie-Greków na zniszczenie. Miciński w dekadenckim wyobrażeniu Konstantynopola wyraźnie nawiązuje do Irydiona. Rzym Krasińskiego również stanowił konglomerat kultur wpływy greckie mieszały się z nordyckimi, tworząc ładunek umożliwiający zagładę rachitycznej cywilizacji. Rzym w czasach Heliogabala był jednakowoż rzeczywiście państwem dążącym do upadku, natomiast Bizancjum w trakcie rządów Romana II, Nikefora III oraz Jana Tzimiskesa stanowił kraj kwitnący, wysoko rozwinięty kulturowo i technologicznie, gwarantujący dobrobyt swym obywatelom. Wydaje się, że Bazilissa Teofanu jest skonstruowana jedynie na bazie utrwalonych przeświadczeń o średniowiecznej Grecji i służy wyłącznie jako narzędzie do wyrażenia określonych treści światopoglądowych, bowiem realia stworzone przez Micińskiego ze źródłami historycznymi mają wspólnego bardzo niewiele. Autor, posługując się wyłącznie przypuszczeniami historyków i plotkami współczesnych Teofano, czyni z tytułowej bohaterki potwora, prawdziwą femme fatale $\mathrm{w}$ średniowiecznym wydaniu. Cesarzowa rzeczywiście była osobą bardzo przebiegłą i żądną władzy, lecz zarazem od swojego literackiego odpowiednika bardzo odległa. Oczywiście licentia poetica zezwala autorowi na konfabulację, jednakowoż tak daleko posunięte odkształcenia w przedstawieniu Bizancjum świadczą niezawodnie o inspiracji zachodnimi wyobrażeniami. Dekadencki obraz Konstantynopola świetnie wpisywał się w predylekcje ideologiczne epoki, Cesarstwo Greckie w Bazilissie Teofanu jest odpowiednikiem upadającej Europy, sięga szczytów wyrafinowania po to, aby gnuśnie opaść w bezdenną otchłan aksjologiczną.

\section{ŻEROMSKI I BIZANCJUM}

Reminiscencje bizantyńskie w Popiołach Żeromskiego pojawiają się w trakcie podróży po Europie jednego z głównych bohaterów - Gintułta. Sentymentalna przechadzka księcia po Wenecji służy jako pretekst do rozważań o dziejach miasta. Wenecja percypowana jest przez bohatera jako wynik multikulturowych kontaktów handlarzy i arystokratów weneckich. Szczególną rolę w rozwoju miasta odegrało Bizancjum, które wymieniane jest parokrotnie w opowieści:

„W mieście tym wyrasta niezmierna liczba świątyń i pałaców, wykwita biblioteka Sansovina, Prokuracje, Kampanila, pałac dożów i sama owa bazylika. Niestrudzeni żeglarze, waleczni żołnierze, najprzemyślniejsi kupcy zwożą w darze dla Świętego Marka wszystko, co gdziekolwiek było cennego. Z Egiptu, Grecji, Bizancjum - kolumny z porfiru i serpentyny, alabastry, wazy, płaskorzeźby egipskie, snycerskie dzieła Persów, słupy z mitycznym pismem ze świątyni Saba w Akrze"11.

Grecja przez niemal całe istnienie Bizancjum należała do Cesarstwa, zaś Akra i Egipt wchodziły w skład tego państwa aż do czasu podbojów arabskich. Wszystkie wymieniane w opisie przedmioty pochodzą z hellenistycznego kręgu kulturowego stanowiącego inspirację dla do-

11 S. Żeromski, Popioły, t. 1, Wrocław 1996, s. 237-238. 
żów. Wenecja rozwijała się dzięki kontaktom z cesarstwem, była zawsze jego sprzymierzeńcem i głównym ogniwem porozumienia z Zachodem. Jednak w 1204 r. obróciła się przeciwko swojemu protektorowi - zbuntowała krzyżowców i skierowała ich do Konstantynopola zamiast do Jerozolimy. Miasto zostało złupione, a większość skarbów - wywieziona na Zachód:

„Większość domów i posiadłości arystokracji została ograbiona ze wszystkiego, co miało jakąkolwiek wartość. Villehardouin twierdzil, że »tylu łupów nie udało się zebrać od momentu stworzenia świata«. Robert z Clari szacował, że była to największa grabież od czasów Aleksandra Wielkiego, lecz narzekał, że większość zdobyczy znalazła się w rękach bogatych i wysoko postawionych, a nie trafiła do zwykłych żołnierzy takich, jak on. Niektóre szacunki określają wartość łupu na około 900 tysięcy srebrnych marek"12.

Pamiątką po grabieży były cztery zabytkowe konie z kwadrygi, która znajdowała się uprzednio na konstantynopolitańskim hipodromie:

„Oto chimeryczne kornyckie konie [ich pochodzenie nie jest wyjaśnione - przyp. K. S.] nad głównym portalem środkowym wspinają się i rwą w świat. Dokąd? Były już przy pogromie Grecji [podbicie Grecji przez Rzymian] i jako symbol tryumfu rwały się w świat na tryumfalnych murach Carogrodu. Były świadkami zwycięstwa Wenecji nad Bizancjum i stanęły tu, u drzwi Św. Marka na pięćset lat”13.

Doża zachwycony potęgą bizantyńską zapragnął zniszczyć ja, aby móc przejąć jej dorobek. Ambiwalentne odczucia Zachodu względem Bizancjum - zazdrość i nienawiść pomieszane z zachwytem - doprowadziły niemal do upadku cesarstwa. Paradoksalnie to, co zostało Grekom odebrane zapładniało kulturę państw śródziemnomorza; na ruinach Konstantynopola kiełkował europejski renesans. Świetność Wenecji również jednak dobiega w powieści Żeromskiego końca, Europa otwiera się na nowy, napoleoński porządek. Czwarta krucjata była początkiem ewolucji średniowiecznej Europy w stronę odrodzenia, panowanie Napoleona jest zaś punktem wyjściowym dla nadejścia nowoczesności - konie bizantyńskie muszą więc zniknąć z Wenecji:

„Przed samym wejściem do katedry stały tęgie słupy rusztowania, a na nich biegali żołnierze. Olbrzymie liny na blokach snuły się w ciągłym ruchu. Nie można było zrozumieć w pierwszej chwili, co się to dzieje. [...] Szarpany na wsze strony, znajdując się co moment to między gawiedzia, to wśród żołnierstwa, książę spostrzegł nareszcie przyczynę. Na linach niezmiernej grubości, wciąż wodą zlewanych, spływał na dół drugi z rzędu koń grecki. Liny sprężyście drgały, tocząc się z wolna po blokach, a wielki koń, ważący blisko dwa tysiące cetnarów, bokiem do ludu zwrócony, posłusznie szedł na dół..." ${ }^{\prime 14}$.

Bazilissa Teofanu i Popioły to dwa przeciwstawne wyobrażenia Bizancjum. Cesarstwo Micinskiego jest tworem opartym na potępiających relacjach z epoki i będącym środkiem wyrazu dla światopoglądu dekadenckiego. Jest jednakowoż sztuka ta czymś szczególnym. Dla Żeromskiego zaś Bizancjum to jeden z głównych filarów europejskiej kultury; czwarta krucjata i upadek Konstantynopola w 1453 r. spowodowały migracje Greków i tym samym - rozprzestrzenienie idei antycznych oraz humanizmu.

12 J. Herrin, Byzantium..., dz. cyt., s. 233.

13 Tamże.

14 Tamże, s. 254. 


\section{LITERATURA PODMIOTU}

Miciński T., W mrokach Złotego Pałacu czyli Bazilissa Teofanu, [w:] tenże, Utwory dramatyczne, Kraków 1979. Mickiewicz A., Wybór poezyj, t. 1, Wrocław 1974

Słowacki J., Żmija, [w:] tenże, Poematy, Krzyżanowski J. (red.), Wrocław 1959.

Żeromski S., Popioły, t. 1, Wrocław 1996.

\section{LITERATURA PRZEDMIOTU}

Bhabha H., Mimikra i ludzie. O dwuznaczności dyskursu kolonialnego, „Literatura na Świecie” 2008, nr 1-2. Herrin J., Byzantium. The surprising life of medieval Empire, New Jersey 2007.

Janion M., Niesamowita słowiańszczyzna. Fantazmaty literatury, Kraków 2006.

\section{Słowa kluczowe}

Bizancjum, literatura, Młoda Polska, Miciński, Żeromski, postkolonializm, Janion.

\section{STRESZCZENIE}

Artykuł pt. Inny hellenizm. Obrazy Bizancjum w literaturze młodopolskiej przybliża początkowo dzieje recepcji Cesarstwa Greckiego w piśmiennictwie polskim. Autor stwierdza, iż temat ten był bardzo często pomijany bądź też tylko w niewielkim stopniu wzmiankowany. Tekst, przy wykorzystaniu Niesamowitej słowiańszczyzny Marii Janion, udowadnia, dlaczego zainteresowanie Bizancjum było tak niewielkie. Posługując się kategoriami Wschodu, Zachodu i orientalizacji, zanalizowane zostają dwa dzieła: W mrokach Złotego Pałacu czyli Bazilissa Teofanu Tadeusza Micińskiego oraz Popioły Stefana Żeromskiego.

\section{A different Hellenism. The portrayal of Byzantium in the literature of Young Poland}

\section{Keywords}

Byzantium, literature, Young Poland, Miciński, Żeromski, post-colonialism, Janion.

\section{Summary}

The paper A different Hellenism. The portrayal of Byzantium in the literature of Young Poland examines firstly the reception of the Greek Empire in the Polish literature. The author states that this topic has been very often omitted or only briefly mentioned. The essay, referring to Niesamowita słowiańszczyzna by Maria Janion, proves why the interest in Byzantium has been so slight. Using the categories of East, West and orientalisation, two works are analyzed: W mrokach Złotego Pałacu czyli Bazilissa Teofanu by Tadeusz Miciński and Popioły by Stefan Żeromski. 